\title{
Treg-mediated immunosuppression involves activation of the Notch-HES1 axis by membrane-bound TGF- $\beta$
}

\author{
Marina Ostroukhova, ${ }^{1}$ Zengbiao Qi, ${ }^{1}$ Timothy B. Oriss, ${ }^{1}$ \\ Barbara Dixon-McCarthy, ${ }^{1}$ Prabir Ray, ${ }^{1,2}$ and Anuradha Ray ${ }^{1,2}$ \\ 'Department of Medicine, Division of Pulmonary, Allergy, and Critical Care Medicine, and \\ 2Department of Immunology, University of Pittsburgh School of Medicine, Pittsburgh, Pennsylvania, USA.
}

\begin{abstract}
Studies in humans and mice show an important role for Tregs in the control of immunological disorders. The mechanisms underlying the immunosuppressive functions of Tregs are not well understood. Here, we show that $\mathrm{CD}^{+} \mathrm{T}$ cells expressing Foxp 3 and membrane-bound TGF- $\beta$ (TGF- $\beta^{\mathrm{m}+}{ }^{\mathrm{F} o x p} 3^{+}$), previously shown to be immunosuppressive in both allergic and autoimmune diseases, activate the Notch1-hairy and enhancer of split 1 (Notch1-HES1) axis in target cells. Soluble TGF- $\beta$ and cells secreting similar levels of soluble TGF- $\beta$ were unable to trigger Notch 1 activation. Inhibition of Notch1 activation in vivo reversed the immunosuppressive functions of TGF- $\beta^{\mathrm{m}+} \mathrm{Foxp}^{+}$cells, resulting in severe allergic airway inflammation. Integration of the TGF- $\beta$ and Notch 1 pathways may be an important mechanism for the maintenance of immune homeostasis in the periphery.
\end{abstract}

\section{Introduction}

It is now well accepted that, in both humans and mice, Tregs exist and are important in the control of immunological disorders $(1,2)$. Deficiencies in 1 single gene, Foxp3, expressed by $\mathrm{CD} 4{ }^{+} \mathrm{CD} 25^{+} \mathrm{T}$ cells, cause the immune dysregulation, polyendocrinopathy, enteropathy, X-linked syndrome (IPEX syndrome), with autoimmune responses in multiple organs in both humans and mice due to perturbation of peripheral tolerance (1). Using a model of tolerance induced by repetitive exposure to egg-white allergen (OVA), we recently showed an important regulatory role for $\mathrm{CD} 4^{+} \mathrm{CD} 25^{+} \mathrm{T}$ cells expressing Foxp 3 and membrane-bound TGF- $\beta$ (TGF- $\beta^{\mathrm{m}+} \mathrm{Foxp}^{+}$) in tolerance to inhaled OVA (3). Isolated from the same mice, cells secreting similar levels of soluble TGF- $\beta$ but without membrane-bound TGF- $\beta$ or Foxp 3 did not have suppressive functions (3).

The mechanisms by which Tregs cause immunosuppression are an area of intense investigation in many laboratories (4). The importance of TGF- $\beta$ as a key immunoregulatory mediator was first described in the context of TGF- $\beta$-secreting Th3 cells in studies of oral tolerance (5). Subsequently, CD ${ }^{+} \mathrm{CD} 25^{+} \mathrm{T}$ cells expressing membrane-bound TGF- $\beta$ with suppressive functions were described (6). Studies of immune regulation in diverse model systems, including allergen-induced tolerance (3) and type 1 diabetes (7), have identified suppressive properties of $\mathrm{T}$ cells that secrete soluble TGF- $\beta$ and also express cell surface-bound TGF- $\beta$. Recently, tolerance induced by orally delivered antigen was also reported to be dependent on TGF- $\beta$-dependent, but IL-10-independent, mechanisms mediated by Foxp3-expressing $\mathrm{CD} 4^{+} \mathrm{CD} 25^{+}$ Tregs (8). A recent report has shown an important role for TGF- $\beta$ in the maintenance of Foxp3 expression and suppressor function of peripheral $\mathrm{CD} 4^{+} \mathrm{CD} 25^{+}$Tregs (9).

Nonstandard abbreviations used: BAL, bronchoalveolar lavage; HES1, hairy and enhancer of split 1; NICD, intracellular domain of Notch; pSmad3, phospho-Smad3. Conflict of interest: The authors have declared that no conflict of interest exists. Citation for this article: J. Clin. Invest. 116:996-1004 (2006). doi:10.1172/JCI26490.
The molecule TGF- $\beta$ is conserved in evolution in both vertebrates and invertebrates and plays an important role in cell fate decisions (10). A second molecule with similar functions that is also well preserved in evolution is Notch (11-13). Inhibitory effects of Notch on neuronal differentiation are well documented (14). In a study of mucosal tolerance, when antigen-pulsed APCs overexpressing the Notch ligand Jagged-1 were introduced into mice, lymph node $\mathrm{T}$ cells isolated from the mice were profoundly inhibited from proliferation (15). Overexpression of Jagged-1 in human B cells also induced Tregs (16), as did overexpression of constitutively active Notch3 in transgenic mice (17). After engagement with its ligands, such as Jagged-1, 2 successive proteolytic events cause clipping of the Notch protein. The first is mediated by ADAM proteases and the second by the $\gamma$-secretase complex, in which presenilins (PS1 and PS2) constitute the active center of the enzyme complex. These proteolytic events ultimately release the intracellular domain of Notch (NICD) $(11,12)$. The released NICD translocates to the nucleus and activates transcription of target genes such as hairy and enhancer of split 1 (HES1). HES1 is a basic helix-loop-helix-type transcriptional repressor and negatively regulates gene transcription, best described in studies of neuronal differentiation (11). It appears that Notch exercises diverse effects on cellular processes in a context-dependent fashion. While Notch signaling has been associated with many cancers, in certain instances, Notch, particularly Notch1, when present in high levels, is considered to be a tumor suppressor (13). Although Notch is known to be important for T cell development $(18,19)$, little is known about the utilization of this pathway in $\mathrm{T}$ cell homeostasis in response to antigens. Interestingly, while homozygous presenilin (PS1-/-PS2 ${ }^{-/}$) knockouts are embryonically lethal, as are Notch knockouts, PS1 ${ }^{+/-P S 2-/-}$ mice can survive and reach adulthood; but these mice were recently shown to develop severe autoimmune disease, although the underlying reason was not identified (20).

Given the importance of both Notch and TGF- $\beta$ pathways in cell fate decisions, and induction of the Notch1-HES1 axis by persistent TGF- $\beta$ receptor activation using a constitutively active mutant 

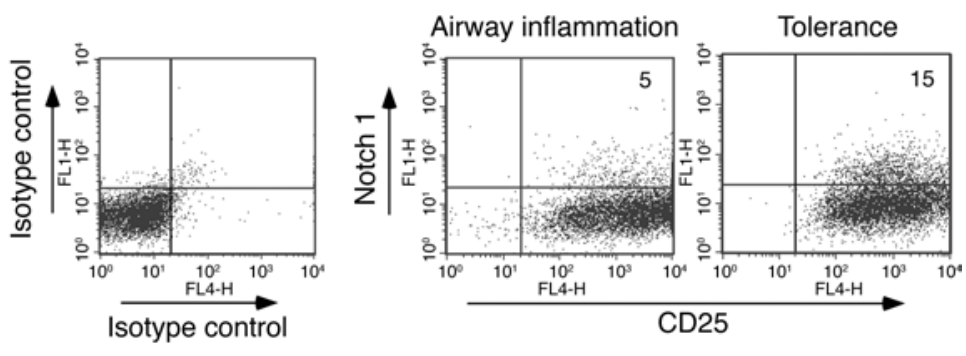

Figure 1

Upregulation of cell surface expression of Notch1 on CD4 ${ }^{+} \mathrm{T}$ cells from tolerized mice. Mice were exposed for 10 successive days to PBS (mice subsequently develop airway inflammation after OVA/alum immunization followed by OVA aerosol exposure) or to 1\% OVA (to develop tolerance). Both groups were immunized with OVA/alum on days 21 and 27 , and spleens were isolated (3). Spleens from 3 animals were pooled in each group, and CD4+ $T$ cells were isolated and subjected to stimulation with OVA/APCs in vitro. The cells were stained for the expression of CD4, CD25, and Notch1. Since no staining was detected in the top left quadrants of the "Airway inflammation" and "Tolerance" panels, the total fluorescence value in the FL1 channel for the isotype control stain (top left and top right quadrants) was subtracted from the experimental stains to arrive at net percent-positive values of $5 \%$ and $15 \%$ for the airway inflammation and tolerance conditions, respectively. Expression of CD25 and Notch1 was determined on equal numbers of CD4+ $T$ cells for each condition. Numbers in the dot plots denote percentages. Results shown are representative of 4 independent experiments.

of type I TGF- $\beta$ receptor in embryonic cells (21), we hypothesized that cell surface TGF- $\beta$ on TGF- $\beta^{\mathrm{m}+} \mathrm{Foxp}^{+}$Tregs engages the Notch pathway in the induction of antigen-induced tolerance in the respiratory tract. Our studies identify integration of the TGF- $\beta$ and Notch pathways in antigen-induced peripheral tolerance.

\section{Results}

Enhanced Notch1-HES1 activation in antigen-induced tolerance compared with inflammation. To investigate the possible role of Notch in the development of tolerance, we subjected BALB/c mice to a model of tolerance induced by antigen (OVA), involving repeated exposure to inhaled antigen as previously described $(3,22)$. $\mathrm{CD}^{+} \mathrm{T}$ cells isolated from tolerized mice and mice immunized for the development of airway inflammation were stimulated with OVA ex vivo, and the expression of Notch 1 was investigated. Although the $\mathrm{CD} 4^{+}$ $\mathrm{T}$ cells isolated from the inflammation group proliferated more in comparison with those isolated from the tolerance group, as described previously (3), the cells from the tolerance group displayed a higher level of Notch1 expression (Figure 1).

Upregulation of Notch1 on target cells by cells expressing membranebound TGF- $\beta$. We established an assay system to directly assess Notch1 expression in response to cells expressing membranebound TGF- $\beta$ (TGF- $\left.\beta^{\mathrm{m}+}\right)$ isolated from tolerized mice, which have regulatory function (3). In this assay, $\mathrm{CD}^{+} \mathrm{T}$ cells isolated from DO11.10 TCR transgenic mice, which are recognized by the clonotypic KJ1-26 antibody, were used as target cells, and the cells were incubated with either TGF- $\beta^{\mathrm{m}+}$ cells or cells devoid of membranebound TGF- $\beta$ (TGF- $\beta^{\mathrm{m}-}$ ) (Figure 2 , A and B). A small fraction of the cell mix in each group was stained with KJ1-26 and anti-Notch1, and cell extract was derived from the rest. DO11.10 CD4 ${ }^{+} \mathrm{T}$ cells exposed to regulatory TGF- $\beta^{\mathrm{m}+}$ cells showed 2 -fold and 4 - to 5 -fold more Notch 1 expression after 24 (data not shown) and 48 hours of coculture (Figure 2C), respectively. Expression of cleaved Notch1, and HES1, a downstream target of Notch1, was also detected in the extracts prepared from the cell mix containing TGF- $\beta^{\mathrm{m}^{+}}$ and DO11 CD4 ${ }^{+} \mathrm{T}$ cells (Figure 2, D and E). It should be noted that the anti-Notch1 antibody used in this particular experiment recognizes cleaved Notch1 and NICD but not the intact protein.

Expression of Notch ligands by TGF- $\beta^{m+}$ cells. Having previously shown specific immunosuppressive functions of TGF- $\beta^{\mathrm{m}+}$ but not TGF- $\beta^{\mathrm{m}-}$ cells (3), and further demonstrated that only TGF- $\beta^{\mathrm{m}+}$ cells induce Notch activation in target cells (Figure 2E), we examined expression of the Notch ligands on the TGF- $\beta^{\mathrm{m}+}$ cells. Mice were exposed to aerosolized OVA to induce tolerance, and on day 21 after initiation of exposure to OVA, CD $4^{+} \mathrm{CD} 25^{+} \mathrm{T}$ cells were isolated from the spleens of these mice. Simultaneously, $\mathrm{CD} 4^{+} \mathrm{CD} 25^{+} \mathrm{T}$ cells were also isolated from the spleens of naive mice. We first assessed expression of TGF- $\beta^{\mathrm{m}+}$ on these cells by flow cytometry. While approximately $10 \%$ of the $\mathrm{CD} 4^{+} \mathrm{CD} 25^{+}$cells freshly isolated from the tolerized mice were found to express membrane-bound TGF- $\beta$, no TGF- $\beta$ expression was detected on cells isolated from naive mice, as reported by us and others previously $(3,6)$. When expression of Notch ligands on these cells was examined, all of these cells were found to express the 3 ligands Jagged-1, Delta-1, and Delta-4 at a very high level (Figure $3 \mathrm{~A})$. In contrast, when TGF- $\beta^{\mathrm{m}-}$ cells were examined, expression of Jagged-1 and Delta- 4 was not detected, and that of Delta-1 was greatly diminished compared with that in TGF- $\beta^{\mathrm{m}+}$ cells (several orders of magnitude based on mean fluorescence intensity; Figure $3 \mathrm{~B}$ ). The level of Delta-1 staining on TGF- $\beta^{\mathrm{m}-}$ cells was comparable to that on $\mathrm{CD} 4^{+} \mathrm{T}$ cells from naive animals (i.e., was very low), which also lack expression of Jagged-1 and Delta-4 (data not shown).

Activation of the Notch1-HES1 axis by membrane-bound TGF- $\beta$. To determine whether cell surface-associated TGF- $\beta$ has the distinct ability to activate the Notch 1 pathway, we compared the ability of TGF- $\beta^{\mathrm{m}+}$ cells and soluble TGF- $\beta$ (in doses from $1 \mathrm{pg} / \mathrm{ml}$ to $1 \mathrm{ng} / \mathrm{ml}$ ) to induce cleavage of Notch and activate HES1 in target cells. DO11.10 CD $4^{+}$T cells were incubated with TGF- $\beta^{\mathrm{m}+}$ or TGF- $\beta^{\mathrm{m}-}$ cells from tolerized mice or with naive $\mathrm{CD} 4^{+} \mathrm{T}$ cells (to maintain similar cell composition in the mix) plus different doses of soluble TGF- $\beta$ (shown are results with $1 \mathrm{ng} / \mathrm{ml}$ of soluble TGF- $\beta$ ). Cell extracts were prepared from the cocultured cells, and expression of Foxp3 (shown previously by us to be expressed by TGF- $\beta^{\mathrm{m}+}$ but not by TGF- $\beta^{\mathrm{m}-}$ cells), phospho-Smad3 (pSmad3; TGF- $\beta$-inducible factor), NICD, and HES1 was examined in the respective extracts. As noted by others, nuclear NICD is very difficult to detect because of its low abundance (21) and short half-life (23). Foxp3 expression was most prominent when TGF- $\beta^{\mathrm{m}+}$ cells were coincubated with target cells (Figure 4A). Some expression was detected when naive cells were included along with soluble TGF- $\beta$, which could be due to a small population of TGF- $\beta^{\mathrm{m}+}$ cells in naive mice as reported previously by us (3). Interestingly, while as expected, phosphorylated Smad3, an essential feature of TGF- $\beta$ signaling, was detected in each case, NICD and HES1 were detected only when TGF- $\beta^{\mathrm{m}+}$ cells were present in the cell mix (Figure 4A). Since only high doses of soluble TGF- $\beta$ were previously shown to induce Foxp 3 expression in target $\mathrm{CD}^{+} \mathrm{CD} 25^{-} \mathrm{T}$ cells by RT-PCR techniques (24), we assessed the effect of different doses of soluble TGF- $\beta$ on Foxp 3 protein expression in $\mathrm{CD} 4^{+} \mathrm{CD} 25^{-} \mathrm{T}$ cells stimulated in culture using intracellular staining methods. As shown in 

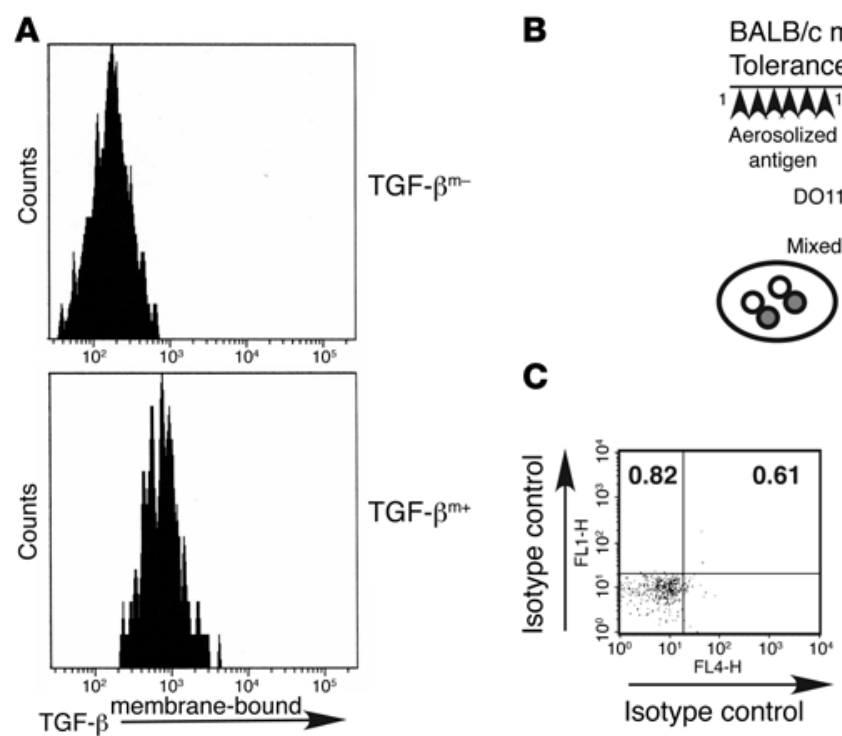

BALB/c mice

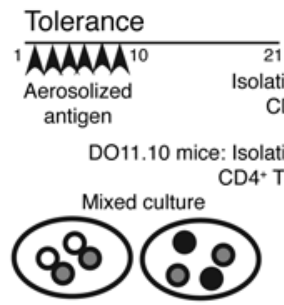

21

CD $4^{+} T$ cells
- $\beta^{m+}$

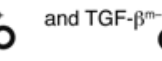

Isolation of

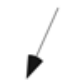

Cells mixed at $1: 1$ ratio

with OVA and APC staining

for flow cytometry, TCE, NE

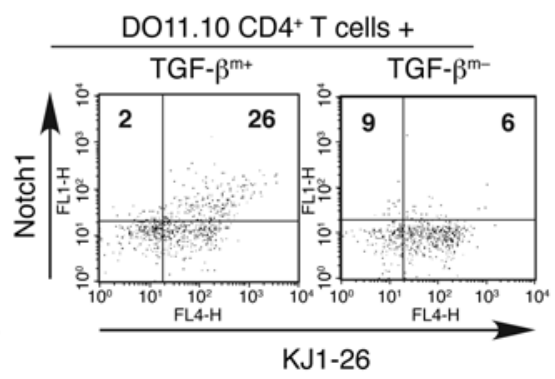

D

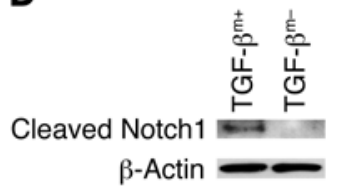

E

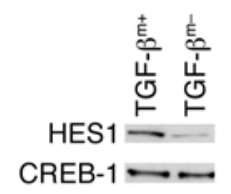

Figure 2

Upregulation of Notch1 on target cells by TGF- $\beta^{m+}$ but not by TGF- $\beta^{m-}$ cells. (A) Post-sort TGF- $\beta$ flow cytometry profile of TGF- $\beta^{\mathrm{m}+}$ and TGF- $\beta^{\mathrm{m}-}$ cells. TGF- $\beta^{\mathrm{m}+}$ cells were induced in mice using the tolerance protocol. On day $21, \mathrm{CD} 4^{+} \mathrm{T}$ cells were prepared by negative selection, and cells expressing TGF- $\beta$ on the cell surface (TGF- $\beta^{\mathrm{m}+}$ ) were separated from those devoid of cell surface TGF- $\beta$ (TGF- $\beta^{\mathrm{m}-}$ ) using 2 rounds of sorting. The purity of the 2 populations was assessed by flow cytometry $\left(\sim 80 \%\right.$ enrichment of TGF- $\beta^{\mathrm{m}+}$ cells). (B) Experimental strategy. TGF- $\beta^{\mathrm{m}+}$ or TGF- $\beta^{\mathrm{m}-}$ cells were mixed with DO11.10 TCR transgenic CD4 ${ }^{+}$T cells (target cells) in a 1:1 ratio and stimulated in vitro with whole OVA protein and APCs. (C) Staining with anti-Notch1 and KJ1-26 antibody or matching isotype control of an aliquot of $10^{5}$ total cells removed after 48 hours of incubation. Each dot plot contains approximately 1,000 events. Numbers in dot plots denote percentages. (D) Western blot analysis of the presence of cleaved Notch1 in total cell extracts (TCEs) prepared from the mixed cultures after 24 hours of incubation using antibody specific to cleaved Notch1. Expression of $\beta$-actin is shown as a marker for protein loading. (E) Analysis of HES1 expression by immunoblotting of nuclear extracts (NEs) prepared after 72 hours of culture. CREB-1 expression was examined to assess protein loading. Results shown are representative of 2 independent experiments.

Figure 4B, a dose-dependent increase in the frequency of Foxp3expressing cells was clearly evident. To demonstrate Notch1 activation induced by membrane-bound TGF- $\beta$ in target DO11 cells, cells were sorted after coculture (Figure 4C), and indeed HES1 expression was noted only in the sorted DO11 cells that were previously incubated with TGF- $\beta^{\mathrm{m}+}$ cells (Figure 4D).

Inbibition of Notch1 activation compromises suppressive function of TGF- $\beta^{m+}$ cells. To test the importance of Notch 1 activation in the suppressor function of TGF- $\beta^{\mathrm{m}+}$ cells, we used an inhibitor of $\gamma$-secretase, the enzyme complex responsible for cleavage of Notch into its active intracellular transactivator NICD. We first carried out a control experiment to test the efficacy of the inhibitor, L-685,458, which has been previously used to block $\gamma$-secretase-mediated Notch signaling (25-27). We examined HES1 activation in the presence or absence of L-685,458 in CD $4^{+}$ $T$ cells stimulated with a combination of soluble anti-CD3 and APCs. As shown in Figure 5A, HES1 activation in stimulated CD4 ${ }^{+}$ $\mathrm{T}$ cells was inhibited in the presence of L-685,458 but not in the presence of the vehicle (DMSO). Having confirmed the inhibitory effect of the $\gamma$-secretase inhibitor, we set up an in vitro cell proliferation assay (28) to test the importance of simultaneous TGF- $\beta$ and Notch signaling in suppression by TGF- $\beta^{\mathrm{m}+} \mathrm{Foxp}^{+}$cells derived from tolerized mice. Unlike $\mathrm{CD}^{+} \mathrm{T}$ cells from tolerized mice, cells from mice immunized for inflammation readily proliferated in a recall response to OVA ex vivo in a dose-dependent fashion (Figure 5B). Their proliferation was, however, inhibited in the presence of cells from tolerized mice, which we previously showed involves cell-cell contact (3). However, use of L-685,458, at doses known to inhibit Notch activation (27), blocked the suppressive effect of TGF- $\beta^{\mathrm{m}+}$ cells (Figure 5B).

TGF- $\beta^{m+}$ cells induce direct interaction between cleaved Notch1 and pSmad 3 in target cells. The ability of an inhibitor of $\gamma$-secretase to block the suppressive function of TGF- $\beta^{\mathrm{m}+}$ cells prompted us to seek biochemical evidence that membrane-bound TGF- $\beta$ does cross-talk with the Notch1 pathway in target cells. In these experiments, we used cell extracts prepared from target DO11.10 cells that were briefly incubated with TGF- $\beta^{\mathrm{m}+}$ cells, TGF- $\beta^{\mathrm{m}-}$ cells, naive $\mathrm{CD} 4^{+} \mathrm{T}$ cells, or soluble TGF- $\beta(2 \mathrm{ng} / \mathrm{ml})$. Cell extracts were prepared, and anti-pSmad3 antibody, coupled to agarose beads, was used to immunoprecipitate pSmad3 from the cell lysates. An isotype was used as a negative control for immunoprecipitation with TGF- $\beta^{\mathrm{m}+}$ cells. As shown in Figure 6, anti-pSmad3 antibody, but not the control antibody, resulted in coimmunoprecipitation of cleaved Notch 1 only when DO11 T cells were incubated with TGF- $\beta^{\mathrm{m}+}$ cells. However, this was not because pSmad3 was present only in this particular cell lysate. As expected, pSmad3 was induced in the DO11 T cells when they were cocultured with TGF- $\beta^{\mathrm{m}-}$ cells, which, we have shown previously, secrete soluble TGF- $\beta$ (3), or when the cells were directly treated with soluble TGF- $\beta$ (Figure 6). No pSmad 3 was detected when DO11 cells were incubated with naive $\mathrm{CD}^{+} \mathrm{T}$ cells (negative control). As previously suggested (3), the biochemical data provided additional evidence that membrane-bound TGF- $\beta$ has specific properties that cannot be substituted by soluble TGF- $\beta$, at least at doses that are otherwise inhibitory for $\mathrm{CD} 4^{+} \mathrm{T}$ cell activation as we and others have previously shown (29-31). 

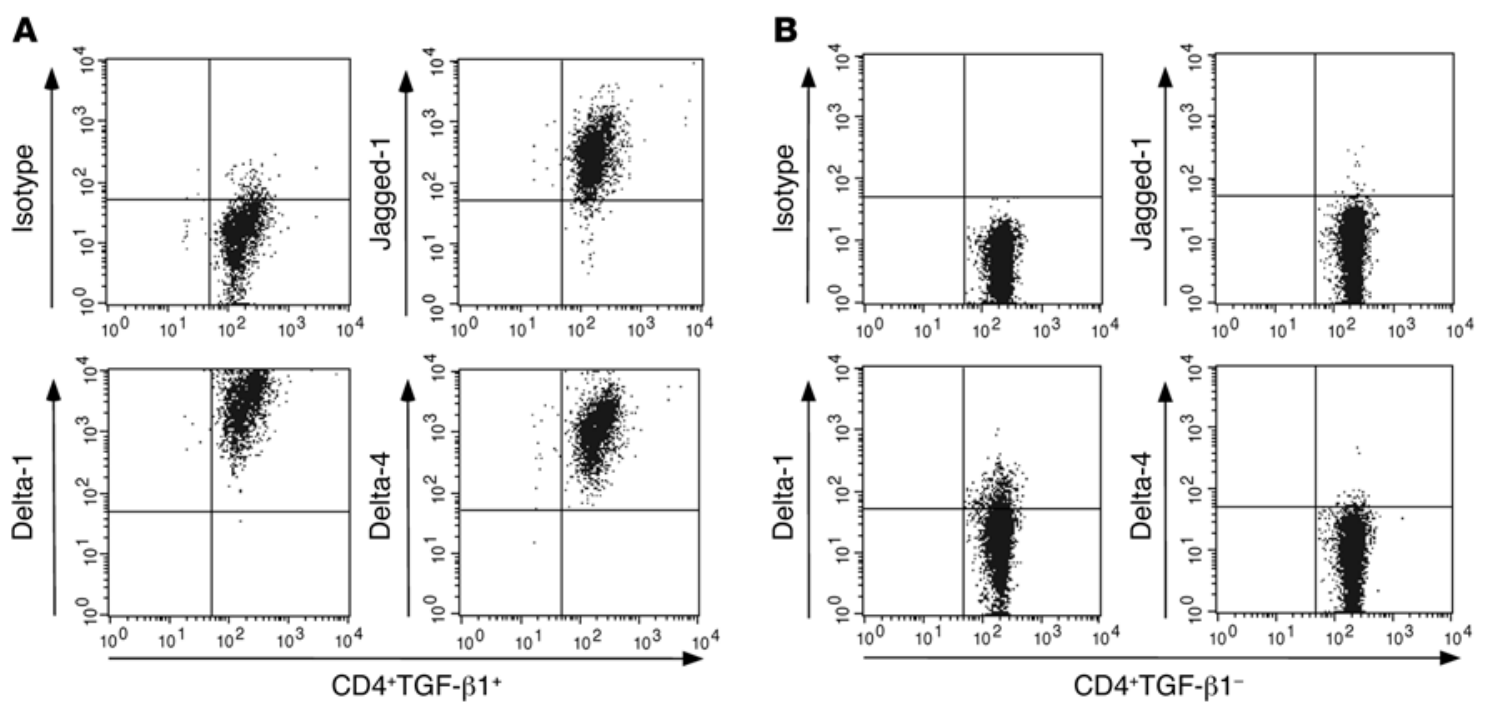

Figure 3

High-level expression of Notch ligands on TGF- $\beta^{m+}$, but not TGF- $\beta^{m-}$, cells. (A) CD4 ${ }^{+}$CD25+ cells were purified from the spleens of naive or tolerized mice. The isolated CD $4^{+} \mathrm{CD} 25^{+}$cells were stained for the expression of surface TGF- $\beta 1$ and either Jagged-1, Delta-1, or Delta-4. No TGF- $\beta^{\mathrm{m}+}$ cells were detected among the CD4+CD25+ cells isolated from naive mice, while $10 \%$ of the CD4+CD25+ cells isolated from tolerized mice expressed TGF- $\beta$ on the cell surface. The dot plots shown were generated by gating on CD4 ${ }^{+}$CD $25^{+}$TGF- $\beta^{\mathrm{m}+}$ cells from tolerized mice after staining with isotype (goat lgG) control, anti-Jagged-1, anti-Delta-1, or anti-Delta-4 antibodies. (B) TGF- $\beta^{\mathrm{m}-}$ T cells from tolerized animals were similarly stained and analyzed for the expression of the 3 Notch ligands. Similar numbers of gated events are shown in each panel.

Blocking Notch1 activation in vivo prevents the ability of TGF- $\beta^{m+}$ cells to suppress allergic airways disease. To test the importance of Notch1 activation in the suppressor function of TGF- $\beta^{\mathrm{m}+}$ cells in vivo, an anti-Notch 1 antibody was used to block Notch 1 activation. This antibody (distinct from the one used to detect cleaved Notch1 or NICD) was previously shown to antagonize Notch1 functions during thymocyte development (32). We first tested the inhibitory function of this antibody toward HES1 induction in target cells by TGF- $\beta^{\mathrm{m}+}$ cells. As shown in Figure 7 , the antibody blocked HES1 activation induced by TGF- $\beta^{\mathrm{m}+}$ cells.

We have previously shown that adoptive transfer of TGF- $\beta^{\mathrm{m}+}$ cells from tolerized mice to naive mice suppresses development of airway inflammation in the recipient mice (3). Using this approach, the relevance of the Notch 1 pathway in suppression in vivo was examined using the anti-Notch 1 antibody (Figure 8 ). The ability of TGF- $\beta^{\mathrm{m}+}$ cells to inhibit all of the hallmarks of allergic airways disease, ranging from antigen-specific IgE levels in the blood to Th2-type cytokine secretion and eosinophilic airway inflammation (Figure 8, group 3), was completely reversed in the presence of anti-Notch 1 but not control antibody (Figure 8, group 5). Interestingly, while the OVA-specific IgE profile shows the dominant inhibitory effect of TGF- $\beta 1$ on Th 2 effects, the OVA-specific IgA levels reflect a dominant effect of Th2 cytokines such as IL-5. While TGF- $\beta 1$ promotes a low frequency of IgA-secreting B cells $(33,34)$, Th2 cytokines, particularly IL-5, amplify this response severalfold $(35,36)$. The low levels of IgA in the bronchoalveolar lavage (BAL) fluid of mice that received TGF- $\beta^{\mathrm{m}+}$ cells with or without isotype control (groups 3 and 6 ) are further proof of the ability of TGF- $\beta^{\mathrm{m}+}$ cells to inhibit Th2-mediated inflammation. Tolerance was similarly inhibited when the anti-Notch 1 antibody was used in conjunction with antigen exposure during the 10-day exposure period (data not shown). Collectively, these data indicate that membrane-bound TGF- $\beta$, induced in $\mathrm{CD} 4^{+} \mathrm{T}$ cells by antigen inhalation (3), requires functional Notch1 to exert its immunosuppressive functions. Although the precise targets of the antiNotch 1 antibody that prevented the immunosuppressive effects of TGF- $\beta^{\mathrm{m}+}$ cells cannot be ascertained from this experiment, a Th cell is a likely target.

\section{Discussion}

Tolerance induced by repeated exposure of mice to inhaled antigen cannot be breached, even by multiple immunizations with antigen and a strong Th2-skewing adjuvant such as alum (22), and we recently implicated $\mathrm{CD}^{+} \mathrm{T}$ cells expressing Foxp3 and membrane-bound TGF- $\beta$ in mediating tolerance in this model (3). First shown by Strober and colleagues to mediate immunosuppression (37), membrane-bound TGF- $\beta$ has also been implicated in suppression of autoimmune type 1 diabetes (7). In the airway inflammation model as well as in the diabetes model, antigen stimulation induces relatively high levels of local TGF- $\beta$ production, which, as previously shown (24), may contribute to induction of membrane-bound TGF- $\beta$ on naive $\mathrm{CD} 4^{+} \mathrm{T}$ cells. In our current study, we analyzed the specific function of membrane-bound TGF- $\beta$ that mediates its immunosuppressive functions. Our studies highlight integration of cell surface-bound TGF- $\beta$-induced signaling and the Notch 1 pathway in immunosuppression by TGF- $\beta^{\mathrm{m}+}$ Foxp $3^{+}$ cells. Integration of these 2 pathways was also recently reported during chronic activation of type I TGF- $\beta$ receptor in chicken embryonic cells (21), during epithelial-mesenchymal transition (38), and during osteogenesis $(39,40)$.

The Notch family of proteins has been implicated in cell fate decisions $(11,12)$. In the nervous system, Notch has a well-established role in cell-cell contact-dependent interactions in the differentiation of neurons and glial cells from common precursor cells (41). Activation of the Notch pathway has been shown to inhibit cellular differentiation, and, conversely, dysfunctional Notch pathways pro- 
A
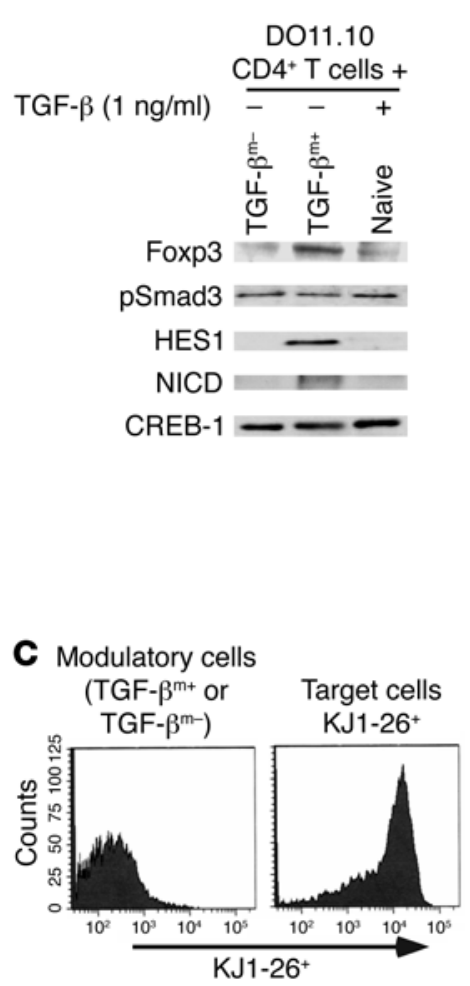

Figure 4

Membrane-bound TGF- $\beta$, but not soluble TGF- $\beta$, activates the Notch1 pathway in target cells. TGF- $\beta^{m+}$ or TGF- $\beta^{m-}$ CD4 ${ }^{+}$T cells were mixed with DO11.10 TCR transgenic CD4 ${ }^{+} T$ cells in a 1:1 ratio and stimulated with OVA (whole protein)/APCs for 1 day. (A) Expression of Foxp3, pSmad3, HES1, and NICD was assessed in nuclear fractions of the cells by Western blot analysis using specific antibodies. CREB-1 expression is shown as a marker for protein loading. Densitometric reading of protein expression revealed pSmad3/CREB-1 ratios of 0.6, 0.4, and 0.7 and Foxp3/CREB-1 ratios of 0.05, 0.4, and 0.1 for TGF- $\beta^{\mathrm{m}-}$, TGF- $\beta^{\mathrm{m}+}$, and soluble TGF- $\beta$ incubations with DO.11 T cells, respectively. (B) Induction of Foxp3 expression in CD4 ${ }^{+}$CD25- $T$ cells treated with different doses of soluble TGF- $\beta$ for 72 hours in the presence of soluble anti-CD3 $(2 \mu \mathrm{g} / \mathrm{ml})$ and T cell-depleted splenocytes. Foxp3 was detected by intracellular staining techniques. Numbers in the dot plots denote percentages. (C) In separate experiments, after 3 days of coculture, the target KJ1-26+ DO11.10 TCR transgenic T cells were sorted from the modulatory KJ1-26TGF- $\beta^{\mathrm{m}+}$ or TGF- $\beta^{\mathrm{m}-}$ cells, and nuclear extracts were prepared from each fraction. (D) Analysis of HES1 expression by immunoblotting of nuclear extracts of KJ1-26- and KJ1-26+ $\mathrm{FACS}-\mathrm{K}^{-}$rted cells.

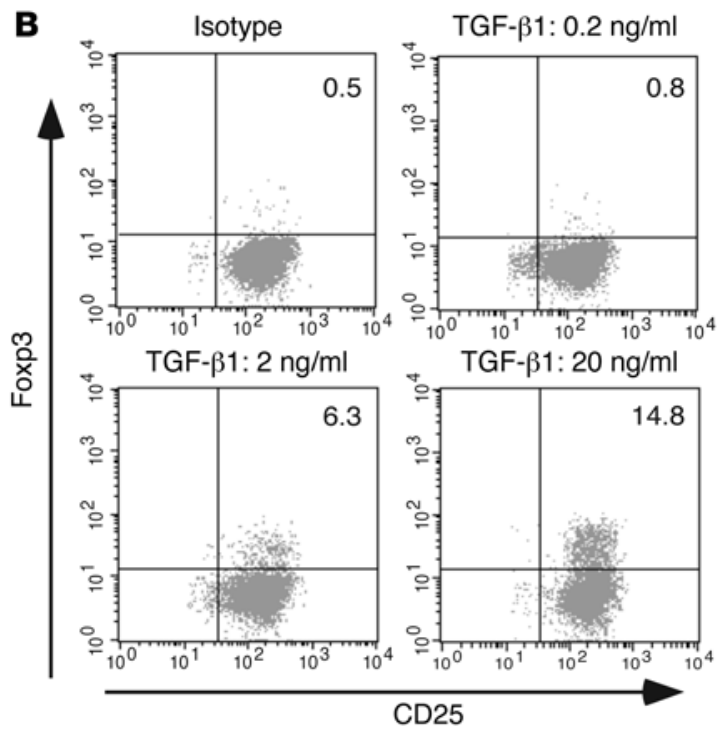

D

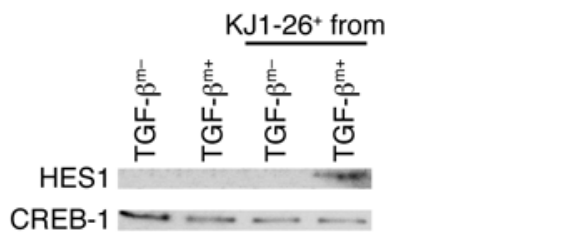

mote premature neuronal differentiation. While hyperactivation of Notch has been associated with malignancies (13), Notch1 has been shown to function as a tumor suppressor in the mouse skin (42). In the immune system, the Notch pathway has been most studied in the area of lymphocyte development (18). Studies by Lamb and colleagues first showed that overexpression of Jagged-1 (also called Serrate-1) dampens pulmonary immune responses (15). A recent study has also shown inhibition of T cell activation by Notch (43). Our studies show, for the first time to our knowledge, that in antigen-induced tolerance, activation of the TGF- $\beta$-TGF- $\beta$ receptor axis on a target $\mathrm{T}$ cell by cell surface-bound TGF- $\beta$ expressed by a Treg triggers Notch activation in the target cell, inhibiting $\mathrm{T}$ cell activation. Furthermore, inhibition of Notch1 activation using either an antibody (32) or a specific $\gamma$-secretase inhibitor (25-27) attenuates the immunosuppressive potential of TGF- $\beta^{\mathrm{m}+}{ }^{+} \mathrm{Foxp}^{3+}$ cells that are integral to antigen-induced tolerance in our model (3).
It is interesting that a relatively high dose of soluble TGF- $\beta$ that is sufficient to block naive $\mathrm{CD} 4^{+} \mathrm{T}$ cell differentiation (29-31) was unable to cause Notch activation in target cells despite Smad3 activation by both soluble and membrane-bound TGF- $\beta$. Since Notch1 activation in chicken embryonic cells was shown to be induced by a constitutively active mutant of TGF- $\beta$ receptor (21), it is likely that sustained signaling by membrane-bound TGF- $\beta$ is required for Notch 1 activation that cannot be achieved by soluble TGF- $\beta$. While Notch has been implicated in inhibition of $\mathrm{CD}^{+} \mathrm{T}$ cell activation $(15,43)$, it has been also associated with $\mathrm{T}$ cell differentiation/activation using $\mathrm{T}$ cell/APC or antibody stimulation approaches (44-46). It is unclear at this time why integration of the TGF- $\beta$ / Smad pathway with Notch/HES1 inhibits $\mathrm{T}$ cell activation when the same pathway (Notch/HES1) is also utilized during $\mathrm{T}$ cell activation. We did observe sustained HES1 activation in $\mathrm{CD}^{+} \mathrm{T}$ cells from the tolerance group compared with that found in the inflammation group, which suggests that prolonged activation of HES1 in tolerance may induce downstream events that cannot be induced during transient HES1 activation. It is intriguing that mice deficient in presenilins, which have deficient Notch activation, develop severe autoimmune disease (20); this suggests a role for Notch in the maintenance of peripheral tolerance. There is precedent in the cancer literature for differential effects of Notch1 where very high doses of Notch 1 cause suppression of the transforming effects of human papillomavirus E6 and E7 proteins while moderate levels of Notch1 can induce proliferation and survival (47). In $\mathrm{CD} 4^{+} \mathrm{T}$ cells, the same Notch 1 molecule can transduce distinct signals depending on whether Notch1 is activated in the presence or the absence of TGF- $\beta \mathrm{m} / \mathrm{Smad} 3$. One possibility is that sustained signaling by TGF- $\beta^{\mathrm{m}}$, in turn, induces sustained Notch1 signaling, resulting in immunosuppression, while transient Notch1 activation in the presence of TCR signaling causes $\mathrm{T}$ cell activation/differentiation (44-46). Thus, antigen-triggered TCR signaling may cause Notch1-mediated T cell activation or suppression depending on whether TCR activation occurs in the absence or the presence of TGF- $\beta^{\mathrm{m}}$-induced signaling.

The order of events that induces expression of membrane-bound TGF- $\beta$ on $C D 4^{+} \mathrm{CD} 25^{+}$cells has yet to be determined. It is likely that tolerance in specific organs such as the lung (3) or the pan- 
A

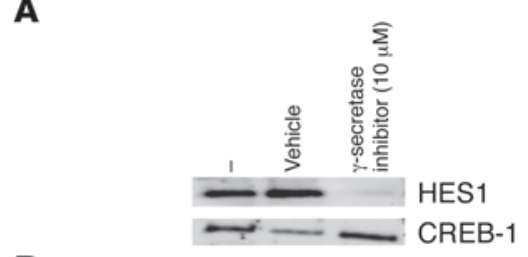

B

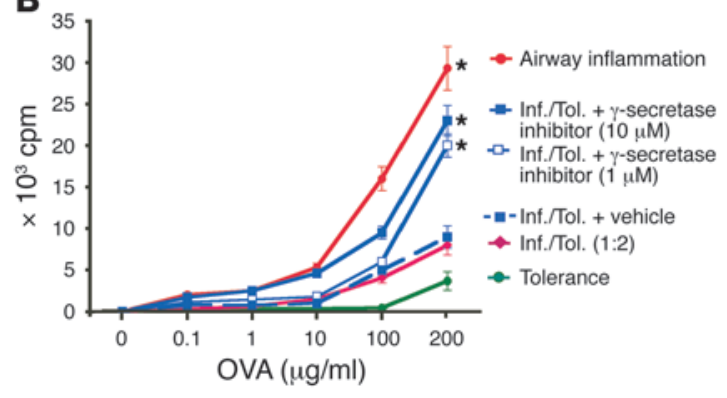

Figure 5

Reversal of suppression by TGF- $\beta^{\mathrm{m}+}$ cells by inhibition of Notch1 signaling. (A) The $\gamma$-secretase inhibitor L-685,458 inhibits Notch1-induced HES1 activation in stimulated CD4 ${ }^{+} \mathrm{T}$ cells. Naive CD4 ${ }^{+} \mathrm{T}$ cells were stimulated with soluble anti-CD3 $(2 \mu \mathrm{g} / \mathrm{ml})$ plus APCs for 16 hours in the presence or absence of L- 685,458 or $0.1 \%$ DMSO (vehicle). Nuclear extracts were prepared, and presence of HES1 was determined by immunoblotting. CREB-1 expression was assessed as a control for protein loading. (B) The $\gamma$-secretase inhibitor reverses the suppressive functions of TGF- $\beta^{\mathrm{m}+}$ cells. Mice were first exposed to PBS (inflammation group; Inf.) or $1 \%$ OVA (tolerance group; Tol.) daily for 10 days and were then immunized with OVA/alum on days 21 and 27 . Splenic CD4+ T cells isolated on day 34 were stimulated in vitro with different concentrations of OVA (1-200 $\mu \mathrm{g} / \mathrm{ml})$ and mitomycin C-treated, T cell-depleted APCs at equivalent cell numbers $\left(10^{5}\right.$ cells each per well). In mixed cultures containing $\mathrm{CD}^{+}{ }^{+} \mathrm{T}$ cells from both groups, twice the number of cells from the tolerance group was added. The $\gamma$-secretase inhibitor L-685,458 was added at a concentration of 1 or $10 \mu \mathrm{M}$. After 72 hours of incubation, cells were pulsed with $\left[{ }^{3} \mathrm{H}\right]$ thymidine to assess cell proliferation. The proliferative response of $C D 4+T$ cells from naive mice is shown as a negative control. ${ }^{*} P<0.05$, mixed cultures with inhibitor treatment versus cultures without treatment. Each data point represents the mean \pm SEM of triplicate wells. Shown is a representative experiment of 3.

creatic islets (7) involves local secretion of substantial amounts of TGF- $\beta$, which promotes expression of cell surface TGF- $\beta$ and concomitant expression of Foxp 3 in $\mathrm{CD} 4{ }^{+} \mathrm{CD} 25^{-} \mathrm{T}$ cells. Alternatively, naturally occurring $\mathrm{CD} 4^{+} \mathrm{CD} 25^{+} \mathrm{T}$ cells may be induced to express membrane-bound TGF- $\beta$ by high concentrations of TGF- $\beta$. In a recently reported study, naturally occurring Tregs were found not to contribute to the development of airway tolerance induced by orally administered antigen (8). It will be interesting to determine whether, in our model, naturally occurring Tregs also play an insignificant role in tolerance induction.

A recent report has shown dependence on TGF- $\beta$ signaling for sustained Foxp3 expression in peripheral $\mathrm{CD} 4^{+} \mathrm{CD} 25^{+} \mathrm{T}$ cells (9). Interestingly, TGF- $\beta$ has been shown to upregulate Jagged-1 expression on renal epithelial cells (48), and since overexpression of Jagged-1 inhibits the development of airway inflammation $(15)$, it is tempting to speculate that high levels of TGF- $\beta$ may promote expression of Notch ligands on APCs and probably also on $\mathrm{CD} 4{ }^{+} \mathrm{CD} 25^{+} \mathrm{T}$ cells as observed in this study. Since mice deficient in presenilins develop severe autoimmune disease (20), the Notch1 pathway may be a common mechanism for maintenance of immune homeostasis in both naive and antigen-provoked animals. Pharmacological efforts to locally activate Notch1 at the site of inflammation (lungs in asthma or joints in rheumatoid arthritis) may prove to be a novel approach to tame aberrant immune activation in chronic inflammatory disease states.

\section{Methods}

Mice. BALB/cByJ mice between 6 and 8 weeks of age were purchased from Jackson Laboratory. DO11.10 T cell TCR transgenic mice were bred and maintained in the Department of Laboratory Animal Resources at the University of Pittsburgh. The mice were housed and used in a pathogen-free facility at the University of Pittsburgh School of Medicine in accordance with all applicable guidelines. Animal studies were performed according to institutional guidelines of animal use and care. All procedures used on animals were reviewed and approved by the Institutional Animal Care and Use Committee of the University of Pittsburgh School of Medicine.

Antibody and reagents. OVA was from Sigma-Aldrich. Peridinin chlorophyll-a protein-labeled (PerCP-labeled) anti-mouse CD4 (RM4-5) and allophycocyanin-labeled anti-mouse CD25 (PC611) were from BD Biosciences - Pharmingen. Anti-HES1 antibodies were a gift from T. Sudo (Toray Industries Inc., Tokyo, Japan). R-phycoerythrin-labeled anti-human TGF- $\beta$ (TB21) from IQ Products Co. (batch no. 40609) was used for sorting TGF- $\beta^{\mathrm{m}+}$ cells, and for all staining purposes, biotinylated polyclonal chicken IgY antiTGF- $\beta 1$ antibody from R\&D Systems was used. Allophycocyanin-labeled anti-mouse DO11.10 TCR (KJ1-26) was from CALTAG Laboratories. Antibody specific to cleaved Notch1 (Val1744) and anti-pSmad3 (Ser433/435) antibody were from Cell Signaling Technology. Anti-Foxp3 and anti- $\beta$-actin antibodies used for immunoblotting were from Novus Biologicals Inc., and anti-Foxp3 antibody for intracellular staining was from eBioscience. AntiNotch1 (clone A6) was from NeoMarkers and was developed in the laboratory of L. Miele (University of Illinois at Chicago, Chicago, Illinois, USA). Recombinant human TGF- $\beta 1$ was purchased from R\&D Systems. The $\gamma$-secretase inhibitor L-685,458 was from Sigma-Aldrich. Anti-CREB- 1 antibody was from Santa Cruz Biotechnology Inc.

Immunization of mice. The protocol for tolerance induction and assessment consisted of a 42-day regimen involving an initial 10-day consecutive antigen exposure to aerosolized 1\% OVA (in PBS), followed (after an interval of rest) by immunization with OVA/alum i.p. twice, followed (after another resting period) by exposure to aerosolized OVA for 7 successive days, as previously described (3).

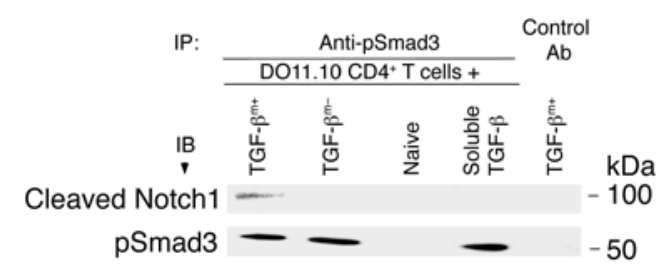

\section{Figure 6}

Membrane-bound TGF- $\beta$, but not soluble TGF- $\beta$, induces interaction between cleaved Notch1 and pSmad3. DO11.10 CD4+ T cells were cocultured with TGF- $\beta^{\mathrm{m}+}$ cells, TGF- $\beta^{\mathrm{m}-}$ cells, naive CD4+ $\mathrm{T}$ cells, or soluble TGF- $\beta$ ( $2 \mathrm{ng} / \mathrm{ml})$ for 24 hours, and cell extracts were prepared. The extracts were subjected to immunoprecipitation using anti-pSmad3 or isotype control (with TGF- $\beta^{\mathrm{m}+}$ cells). The immunoprecipitates were analyzed by immunoblotting with antibody against cleaved Notch1, and the blot was stripped and reprobed with anti-pSmad3. While all lysates contained similar levels of Smad3, which is constitutively expressed in cells (data not shown), Smad3 was phosphorylated in the presence of TGF- $\beta^{\mathrm{m}+}$ cells, TGF- $\beta^{\mathrm{m}-}$ cells, or soluble TGF- $\beta$, but not naive cells. 


\begin{tabular}{|c|c|c|c|c|}
\hline \multirow{2}{*}{ Anti-Notch1 Ab $(\mu \mathrm{g} / \mathrm{ml})$} & \multicolumn{4}{|c|}{ TGF $-\beta^{\mathrm{m+}}+\mathrm{DO} 11.10$} \\
\hline & - & 1 & 10 & - \\
\hline $\begin{array}{r}\text { Control Ab } \\
\text { HES1 }\end{array}$ & - & - & - & + \\
\hline
\end{tabular}

$B A L$ and lung histology. BAL was performed on day 43 (24 hours after the last aerosol challenge), and cell differentials and cytokine levels in the BAL fluid were assessed as described previously (3). Where needed, a semiquantitative method was used to score lung infiltrates. An infiltrate more than 3 cells deep around bronchovascular bundles was classified as a +5 grade infiltrate, and +1 or lower signified a low degree of inflammation (3).

$O V A$-specific IgE and IgA assays and cytokine assays. ELISA assays to measure OVA-specific serum IgE and cytokines were performed as previously described (3). To determine IgA levels in the BAL fluid, $100 \mu \mathrm{l}$ of $100 \mu \mathrm{g} / \mathrm{ml}$ OVA in HBSS (Invitrogen Corp.) was used to coat 96-well microtiter plates (Corning Inc.) overnight at $4{ }^{\circ} \mathrm{C}$. After washes in $0.05 \%$ Tween-20

\section{Figure 7}

Inhibition of HES1 expression in the presence of anti-Notch1 antibody. TGF- $\beta^{\mathrm{m}+}$ cells were mixed with DO11 T cells in the presence or absence of anti-Notch 1 antibody $(1 \mu \mathrm{g} / \mathrm{ml}$ or $10 \mu \mathrm{g} / \mathrm{ml})$ or control antibody, and HES1 expression was determined in nuclear extracts of the cells. Results are representative of 2 independent experiments.

in PBS, the plates were blocked with $200 \mu \mathrm{l}$ of $10 \%$ FBS in PBS for 2 hours at room temperature and then washed as before. One-hundred-microliter volumes of different dilutions of the BAL fluids in PBS containing $10 \%$ FBS and $0.05 \%$ Tween- 20 were added to the wells, and the plates were incubated overnight at $4^{\circ} \mathrm{C}$. After additional washes, the plates were incubated for 5 hours at $37^{\circ} \mathrm{C}$ with $200 \mu \mathrm{l}$ of a $1: 1,000$ dilution of rat anti-mouse IgA-HRP (SouthernBiotech). The plates were washed and incubated at room temperature for 30 minutes in the dark with $100 \mu \mathrm{l}$ of the substrate (Sigma-Aldrich) and were read at $405 \mathrm{~nm}$ wavelength of light using a microplate reader. Values in the linear range were multiplied by the dilution factor and expressed as $\mathrm{OD}_{405} \pm \mathrm{SD}$.
A
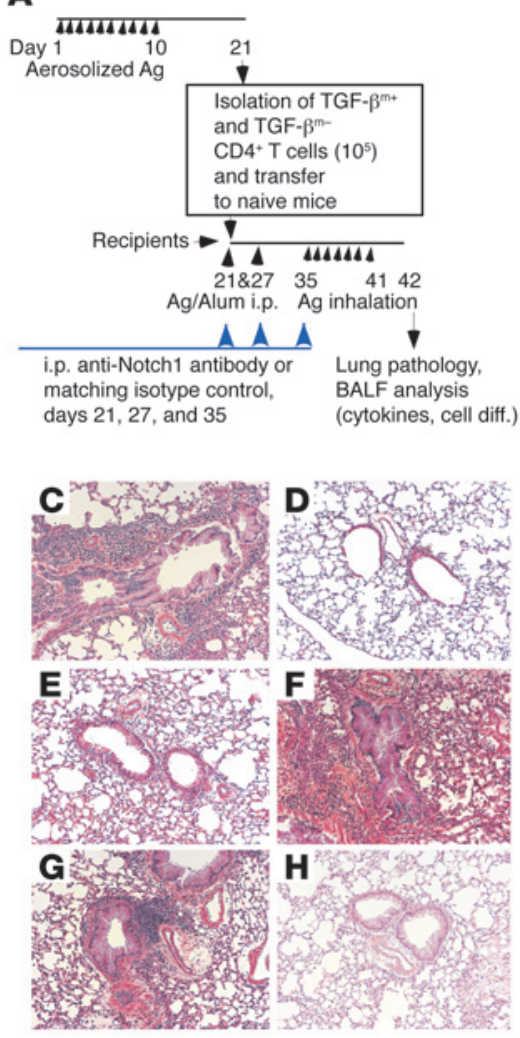

B 1 Airway inf. 2 Tol.

3 TGF- $\beta^{\mathrm{m+}}$

4 TGF- $\beta^{\mathrm{m}-}$

5 Anti-Notch1 + TGF- $\beta^{\mathrm{m}+}$

6 Isotype + TGF- $\beta^{\mathrm{m+}}$
Recipients

subjected to

airway inf.

model
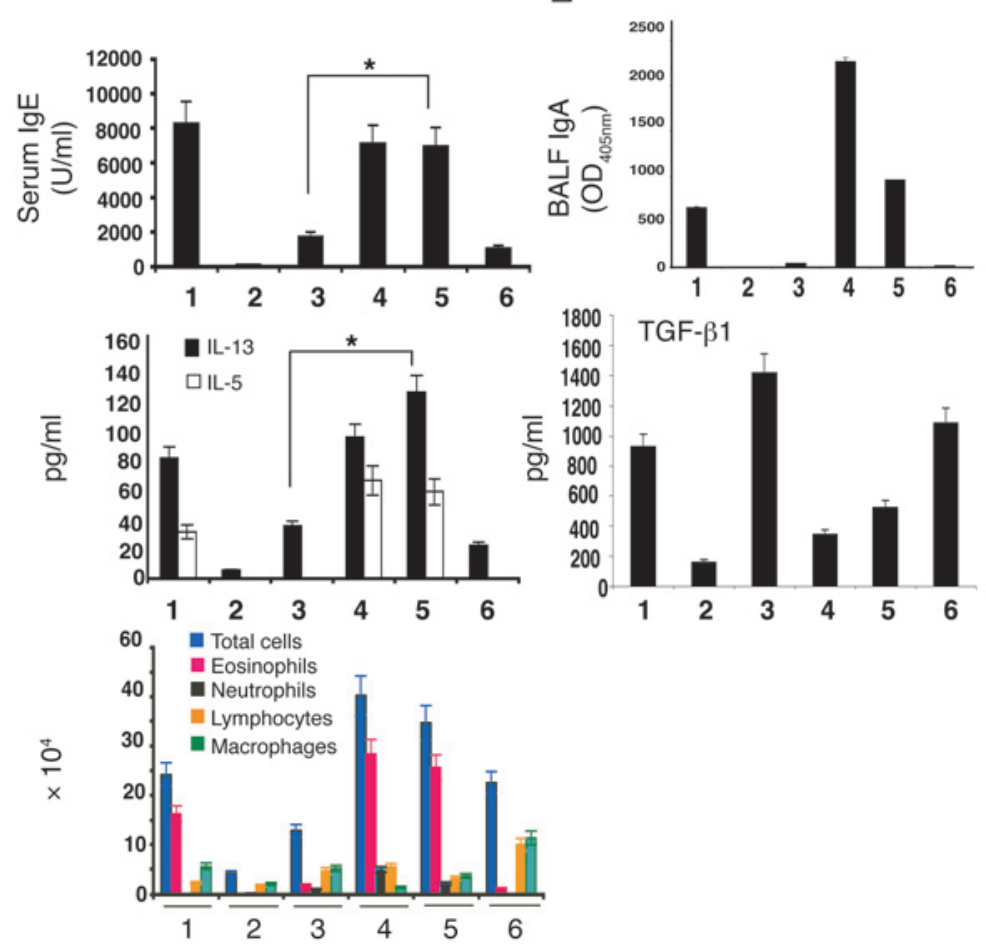

Figure 8

Neutralization of Notch1 prevents active suppression by adoptively transferred TGF- $\beta^{\mathrm{m}+}$ cells. (A) Experimental setup. Anti-Notch1 antibody ( $50 \mu \mathrm{g} / \mathrm{mouse}$ ) or matching isotype control was administrated i.p. into recipient animals 1 hour before OVA/alum injection (days 21 and 27 ) or aerosol challenge (day 35). Control mice were immunized with OVA/alum (airway inflammation) or subjected to the tolerance protocol and challenged with aerosolized OVA. Twenty-four hours after the last OVA challenge, mice were processed for different endpoints. (B) Shown are analysis of IgE in sera and IgA, and cytokine levels (IL-5, IL-13, IL-10 [undetectable] and TGF- $\beta 1$ ) and cell differentials in BALF obtained from 6 groups of animals. Total TGF- $\beta 1$ levels were measured after acid treatment of BALF. Active TGF- $\beta 1$, measured in the absence of acid treatment, was detected at approximately $100 \mathrm{pg} / \mathrm{ml}$ only in the BALF of mice that received TGF- $\beta^{\mathrm{m}+}$ cells (lanes 3 and 6$) .{ }^{*} P<0.05$, TGF- $\beta^{\mathrm{m}+}$ recipients that also received anti-Notch1 antibody versus mice that received TGF- $\beta^{\mathrm{m}+}$ cells alone. (C-H) Tissue histology is also shown. Lung infiltrates were of +5 grade in all TGF- $\beta^{\mathrm{m}-}$ cell transfers $(\mathbf{F})$ or in control OVA/OVA-immunized mice $(\mathbf{C})$, between +4 and +5 in mice that received TGF- $\beta^{\mathrm{m}+}$ cells and anti-Notch1 antibody treatment (G), compared with grades between +1 and +2 in mice that received TGF- $\beta^{\mathrm{m}+}$ cells alone $(\mathbf{E})$ or isotype control $(\mathbf{H})$, or in tolerized mice (D). There were 3 mice per group, and the results are representative of 2 independent experiments. Ag, antigen. Magnification, $\times 40$. 
$\mathrm{CD} 4^{+} \mathrm{T}$ cell isolation from spleen and in vitro stimulation. $\mathrm{CD} 4^{+} \mathrm{T}$ cells were purified by negative selection using a $\mathrm{CD}^{+} \mathrm{T}$ Cell Isolation Kit according to the manufacturer's recommendations (Miltenyi Biotec). Typically, cells were more than $97 \%$ pure, as determined by FACS analysis. APCs were similarly prepared by magnetic depletion of CD4 and CD8 cells followed by treatment with mitomycin C (Sigma-Aldrich) prior to their use in assays. $\mathrm{CD}^{+} \mathrm{T}$ cells together with APCs (1:2 ratio) were cultured with OVA $(100 \mu \mathrm{g} / \mathrm{ml})$ in Bruff's medium (Click's medium [Irvine Scientific] supplemented with $2 \mathrm{mM}$ L-glutamine, $50 \mu \mathrm{M} 2$-mercaptoethanol, $1.3 \mathrm{~g} / \mathrm{l}$ sodium bicarbonate, and $50 \mathrm{mg} / \mathrm{l}$ gentamycin) supplemented with $5 \%$ FCS. Culture supernatants were collected, and then total cell extracts or nuclear extracts were prepared as previously described (3).

Enrichment of cells expressing membrane-bound TGF- $\beta$ (TGF- $\beta^{m^{+}}$and TGF- $\left.\beta^{m-}\right)$. $\mathrm{CD}^{+} \mathrm{T}$ cells expressing TGF- $\beta$ were isolated 10 days after either 10-day aerosol treatment (tolerance) or 2 i.p. injections of OVA plus alum (inflammation) as described above. The $\mathrm{CD}^{+} \mathrm{T}$ cells were purified by negative selection followed first by incubation with R-phycoerythrin-conjugated anti-human TGF- $\beta$ (TB21; IQ Products Co.), then by incubation with anti-phycoerythrin magnetic beads (Miltenyi Biotec). Cells lacking membrane-bound TGF- $\beta$ expression (TGF- $\beta^{\mathrm{m}-}$ ) and those possessing it $\left(\right.$ TGF- $\left.\beta^{\mathrm{m}+}\right)$ were then separated by multiple passes over a magnetic separation column (Miltenyi Biotec). The purity of these cell populations was monitored by flow cytometry and routinely resulted in greater than $80 \%$ enrichment of TGF- $\beta$-expressing cells. In some experiments, cells were purified based on TGF- $\beta$ expression using a FACSAria cell sorter running FACSDiva software (BD Biosciences). After the first sort, cells were resorted to obtain a highly enriched population.

Mixed T cell cultures. The in vitro effects of T cells isolated from the tolerance-group or the inflammation-group animals on DO11.10 TCR transgenic T cells were analyzed. TGF- $\beta^{\mathrm{m}+}$ and TGF- $\beta^{\mathrm{m}-}$ cells were induced and purified as described above. The DO11.10 CD4 ${ }^{+} \mathrm{T}$ cells were purified by positive selection using magnetic bead separation techniques (Miltenyi Biotec). TGF- $\beta^{\mathrm{m}+}$ or TGF- $\beta^{\mathrm{m}-}$ CD $4^{+}$T cells were cultured with DO11.10 T cells in equal numbers and were stimulated with whole OVA protein $(100 \mu \mathrm{g} / \mathrm{ml})$ presented by naive spleen APCs. The T cell/APC ratio was maintained at 1:2. At 24 and 48 hours of incubation, a small portion of the cells were stained for FACS analysis using anti-CD4, anti-Notch1, KJ1-26 (DO11.10 T cell-specific), or appropriate isotype control monoclonal antibodies. After 72 hours of incubation, nuclear and cytoplasmic extracts were prepared from the remaining cells.
In some mixed-culture experiments, DO11.10 T cells were repurified after 3 days by KJ1-26 ${ }^{+}$staining and cell sorting. Nuclear extracts were prepared from the repurified DO11.10 T cells.

Cell proliferation assays. The ability of cells from tolerized animals to inhibit $\mathrm{T}$ cell proliferation was assessed by standard $\left[{ }^{3} \mathrm{H}\right]$ thymidine incorporation assay as previously described (3). Where cells were mixed, $2 \times 10^{5}$ cells from the tolerance group were used. $\gamma$-Secretase inhibitor $(1$ or $10 \mu \mathrm{M})$ or vehicle alone ( $0.1 \%$ final concentration) was added to the mixture of $\mathrm{T}$ cells. Results are reported as the mean \pm SEM of triplicate wells with the background (the mean of triplicate unstimulated wells) subtracted.

Coimmunoprecipitation assay. DO11.10 CD4 ${ }^{+} \mathrm{T}$ cells $\left(2 \times 10^{6}\right.$ cells $)$ were cocultured with TGF- $\beta^{\mathrm{m}+}$ cells, TGF- $\beta^{\mathrm{m}-}$ cells, naive CD $4^{+} \mathrm{T}$ cells (1:1 ratio), or soluble TGF- $\beta(2 \mathrm{ng} / \mathrm{ml})$ for 24 hours, and cell lysates were prepared. Anti-pSmad3 (Cell Signaling Technology) or isotype control was covalently coupled to agarose (Pierce ProFound Co-Immunoprecipitation system), and immunoprecipitation was carried out using $25 \mu \mathrm{g}$ of total protein. Immunoprecipitates were washed and subjected to immunoblotting.

Western blot analysis. Nuclear and cytoplasmic proteins were analyzed by Western blot as previously described (3). For Foxp3 detection, successive overnight incubations at $4^{\circ} \mathrm{C}$ with primary and secondary antibody were carried out.

Statistics. Student's unpaired 2-tailed $t$ test was used for all statistical analyses. Differences between groups were considered significant if $P$ was less than 0.05 .

\section{Acknowledgments}

We thank L. Miele for valuable advice on the use of the anti-Notch1 antibody and for critically reading the manuscript and $\mathrm{T}$. Sudo for his kind gift of anti-HES1 antibody. This work was supported by grants AI48927, HL77430, and P50 HL56389 from the NIH (to A. Ray).

Received for publication August 3, 2005, and accepted in revised form January 24, 2006.

Address correspondence to: Anuradha Ray, Department of Medicine, Division of Pulmonary, Allergy, and Critical Care Medicine, University of Pittsburgh School of Medicine, 3459 Fifth Avenue, MUH A628 NW, Pittsburgh, Pennsylvania 15213, USA. Phone: (412) 802-3191; Fax: (412) 692-2260; E-mail: raya@pitt.edu.

Marina Ostroukhova and Zengbiao Qi contributed equally to this work.
1. Sakaguchi, S. 2004. Naturally arising CD4+ regulatory $\mathrm{T}$ cells for immunologic self-tolerance and negative control of immune responses. Annu. Rev. Immunol. 22:531-562.

2. Baecher-Allan, C., and Hafler, D.A. 2004. Suppressor T cells in human diseases. J. Exp. Med. 200:273-276.

3. Ostroukhova, M., et al. 2004. Tolerance induced by inhaled antigen involves $\mathrm{CD}^{+} \mathrm{T}$ cells expressing membrane-bound TGF- $\beta$ and FOXP3. J. Clin Invest. 114:28-38. doi:10.1172/JCI200420509.

4. Wickelgren, I. 2004. Immunology. Policing the immune system. Science. 306:596-599.

5. Chen, Y., Kuchroo, V.K., Inobe, J., Hafler, D.A., and Weiner, H.L. 1994. Regulatory T cell clones induced by oral tolerance: suppression of autoimmune encephalomyelitis. Science. 265:1237-1240.

6. Nakamura, K., Kitani, A., and Strober, W. 2001. Cell contact-dependent immunosuppression by $\mathrm{CD} 4+\mathrm{CD} 25+$ regulatory $\mathrm{T}$ cells is mediated by cell surface-bound transforming growth factor $\beta$. J. Exp. Med. 194:629-644.

7. Green, E.A., Gorelik, L., McGregor, C.M., Tran, E.H., and Flavell, R.A. 2003. CD4+CD25+ T regulatory cells control anti-islet CD8 $+\mathrm{T}$ cells through TGF-beta-TGF-beta receptor interac- tions in type 1 diabetes. Proc. Natl. Acad. Sci. U. S. A. 100:10878-10883.

8. Mucida, D., et al. 2005. Oral tolerance in the absence of naturally occurring Tregs. J. Clin. Invest. 115:1923-1933. doi:10.1172/JCI24487.

9. Marie, J.C., Letterio, J.J., Gavin, M., and Rudensky, A.Y. 2005. TGF-beta 1 maintains suppressor function and Foxp3 expression in CD4+CD25+ regulatory T cells. J. Exp. Med. 201:1061-1067.

10. Massague, J., Blain, S.W., and Lo, R.S. 2000. TGFbeta signaling in growth control, cancer, and heritable disorders. Cell. 103:295-309.

11. Artavanis-Tsakonas, S., Rand, M.D., and Lake, R.J. 1999. Notch signaling: cell fate control and signal integration in development. Science. 284:770-776.

12. Iso, T., Kedes, L., and Hamamori, Y. 2003. HES and HERP families: multiple effectors of the Notch signaling pathway. J. Cell. Physiol. 194:237-255.

13. Nickoloff, B.J., Osborne, B.A., and Miele, L. 2003. Notch signaling as a therapeutic target in cancer: a new approach to the development of cell fate modifying agents. Oncogene. 22:6598-6608.

14. Sestan, N., Artavanis-Tsakonas, S., and Rakic, P. 1999. Contact-dependent inhibition of cortical neurite growth mediated by notch signaling.
Science. 286:741-746.

15. Hoyne, G.F., et al. 2000. Serrate1-induced notch signalling regulates the decision between immunity and tolerance made by peripheral CD4(+) T cells. Int. Immunol. 12:177-185.

16. Yvon, E.S., et al. 2003. Overexpression of the Notch ligand, Jagged-1 induces alloantigen-specific human regulatory T cells. Blood. 102:3815-3821.

17. Anastasi, E., et al. 2003. Expression of activated Notch3 in transgenic mice enhances generation of $T$ regulatory cells and protects against experimental autoimmune diabetes. J. Immunol. 171:4504-4511.

18. Robey, E. 1999. Regulation of T cell fate by Notch. Annu. Rev. Immunol. 17:283-295.

19. Pear, W.S., and Radtke, F. 2003. Notch signaling in lymphopoiesis. Semin. Immunol. 15:69-79.

20. Tournoy, J., et al. 2004. Partial loss of presenilins causes seborrheic keratosis and autoimmune disease in mice. Hum. Mol. Genet. 13:1321-1331.

21. Blokzijl, A., et al. 2003. Cross-talk between the Notch and TGF-beta signaling pathways mediated by interaction of the Notch intracellular domain with Smad3. J. Cell Biol. 163:723-728.

22. McMenamin, C., Pimm, C., McKersey, M., and Holt, P.G. 1994. Regulation of IgE responses to inhaled anti- 
gen in mice by antigen-specific gamma delta T cells. Science. 265:1869-1871.

23. Rand, M.D., et al. 2000. Calcium depletion dissociates and activates heterodimeric notch receptors. Mol. Cell. Biol. 20:1825-1835.

24. Chen, W., et al. 2003. Conversion of peripheral CD4+CD25- naive $\mathrm{T}$ cells to $\mathrm{CD} 4+\mathrm{CD} 25+$ regulatory $\mathrm{T}$ cells by TGF-beta induction of transcription factor Foxp3. J. Exp. Med. 198:1875-1886.

25. Berechid, B.E., et al. 2002. Identification and characterization of presenilin-independent Notch signaling. J. Biol. Chem. 277:8154-8165.

26. Schroeter, E.H., et al. 2003. A presenilin dimer at the core of the gamma-secretase enzyme: insights from parallel analysis of Notch 1 and APP proteolysis. Proc. Natl. Acad. Sci. U. S. A. 100:13075-13080.

27. Tarassishin, L., Yin, Y.I., Bassit, B., and Li, Y.M. 2004. Processing of Notch and amyloid precursor protein by gamma-secretase is spatially distinct. Proc. Natl. Acad. Sci. U. S. A. 101:17050-17055.

28. Thornton, A.M., and Shevach, E.M. 1998. CD4+CD25+ immunoregulatory T cells suppress polyclonal $\mathrm{T}$ cell activation in vitro by inhibiting interleukin 2 production. J. Exp. Med. 188:287-296.

29. Gorelik, L., Fields, P.E., and Flavell, R.A. 2000. Cutting edge: TGF-beta inhibits Th type 2 development through inhibition of GATA-3 expression. J. Immunol. 165:4773-4777.

30. Heath, V.L., Murphy, E.E., Crain, C., Tomlinson, M.G., and O'Garra, A. 2000. TGF-beta1 down-regulates Th2 development and results in decreased IL-4induced STAT 6 activation and GATA-3 expression. Eur. J. Immunol. 30:2639-2649.

31. Chen, C.H., et al. 2003. Transforming growth factor beta blocks Tec kinase phosphorylation, $\mathrm{Ca} 2+$ influx, and NFATc translocation causing inhibition of T cell differentiation. J. Exp. Med. 197:1689-1699.

32. Yasutomo, K., Doyle, C., Miele, L., Fuchs, C., and Germain, R.N. 2000. The duration of antigen receptor signalling determines $\mathrm{CD} 4+$ versus $\mathrm{CD} 8+$ T-cell lineage fate. Nature. 404:506-510.

33. Ehrhardt, R.O., Strober, W., and Harriman, G.R 1992. Effect of transforming growth factor (TGF)beta 1 on IgA isotype expression. TGF-beta 1 induces a small increase in sIgA+ B cells regardless of the method of B cell activation. J. Immunol. 148:3830-3836.

34. van Ginkel, F.W., et al. 1999. Partial IgA-deficiency with increased Th2-type cytokines in TGF-beta 1 knockout mice. J. Immunol. 163:1951-1957.

35. Sonoda, E., et al. 1992. Differential regulation of IgA production by TGF-beta and IL-5: TGF-beta induces surface IgA-positive cells bearing IL-5 receptor, whereas IL-5 promotes their survival and maturation into IgA-secreting cells. Cell. Immunol. 140:158-172.

36. McIntyre, T.M., Kehry, M.R., and Snapper, C.M. 1995. Novel in vitro model for high-rate IgA class switching. J. Immunol. 154:3156-3161.

37. Nakamura, K., Kitani, A., and Strober, W. 2001 Cell contact-dependent immunosuppression by $\mathrm{CD} 4(+) \mathrm{CD} 25(+)$ regulatory $\mathrm{T}$ cells is mediated by cell surface-bound transforming growth factor beta. J. Exp. Med. 194:629-644.

38. Zavadil, J., Cermak, L., Soto-Nieves, N., and Bottinger, E.P. 2004. Integration of TGF-beta/Smad and Jagged1/Notch signalling in epithelial-tomesenchymal transition. EMBOJ. 23:1155-1165.

39. Zamurovic, N., Cappellen, D., Rohner, D., and Susa, M. 2004. Coordinated activation of notch,
Wnt, and transforming growth factor-beta signaling pathways in bone morphogenic protein 2 -induced osteogenesis. Notch target gene Hey1 inhibits mineralization and Runx2 transcriptional activity. J. Biol. Chem. 279:37704-37715.

40. de Jong, D.S., et al. 2004. Regulation of Notch signaling genes during BMP2-induced differentiation of osteoblast precursor cells. Biochem. Biophys. Res. Commun. 320:100-107.

41. Gaiano, N., and Fishell, G. 2002. The role of notch in promoting glial and neural stem cell fates. Annu. Rev. Neurosci. 25:471-490.

42. Nicolas, M., et al. 2003. Notch1 functions as a tumor suppressor in mouse skin. Nat. Genet. 33:416-421.

43. Eagar, T.N., et al. 2004. Notch 1 signaling regulates peripheral $\mathrm{T}$ cell activation. Immunity. 20:407-415.

44. Palaga, T., Miele, L., Golde, T.E., and Osborne, B.A. 2003. TCR-mediated Notch signaling regulates proliferation and IFN-gamma production in peripheral T cells. J. Immunol. 171:3019-3024.

45. Maekawa, Y., et al. 2003. Delta1-Notch3 interactions bias the functional differentiation of activated CD4+ T cells. Immunity. 19:549-559.

46. Amsen, D., et al. 2004. Instruction of distinct CD4 $\mathrm{T}$ helper cell fates by different notch ligands on antigen-presenting cells. Cell. 117:515-526.

47. Lathion, S., Schaper, J., Beard, P., and Raj, K. 2003. Notch1 can contribute to viral-induced transformation of primary human keratinocytes. Cancer Res. 63:8687-8694.

48. Morrissey, J., et al. 2002. Transforming growth factor-beta induces renal epithelial jagged-1 expression in fibrotic disease. J. Am. Soc. Nephrol. 13:1499-1508. 